Research Article

\title{
Experimental Study on Basic Mechanical Properties of Steel Fiber-Reinforced Siliceous Wet Shotcrete
}

\author{
Xu Yan (D), Li-min Liu (D), Jin-peng Zhang, Yan-hui Li, and He Wang \\ College of Mining and Safety Engineering, Shandong University of Science and Technology, Qingdao 266590, China \\ Correspondence should be addressed to Xu Yan; yanxuhhu@163.com
}

Received 11 May 2018; Revised 30 August 2018; Accepted 10 September 2018; Published 22 October 2018

Academic Editor: Paolo Andrea Carraro

Copyright @ $2018 \mathrm{Xu}$ Yan et al. This is an open access article distributed under the Creative Commons Attribution License, which permits unrestricted use, distribution, and reproduction in any medium, provided the original work is properly cited.

In order to solve the problem of low strength and easy cracking of shotcrete in permanent support of tunnel single shell lining, the effects of steel fiber-reinforced siliceous on mechanical properties of wet shotcrete were investigated by the tests of compressive strength, splitting tensile strength, flexural strength, shear strength, and bending toughness. The strength and the cracking resistance mechanism of steel fiber-reinforced siliceous wet shotcrete were analyzed by the bending toughness evaluation method. The results show that (1) the steel fiber-reinforced siliceous can improve splitting tensile, flexural, and shear capacity of the shotcrete, and the maximum growth rates were $77.42 \%, 72.73 \%$, and $98.31 \%$. The steel fiber plays a major role, and silica fume plays a subsidiarity role. (2) The effect of different types and contents of steel fibers on the compressive strength of wet shotcrete are not obvious. (3) The strengthening effect of shear undaform steel fiber on concrete is obviously better than that of shear flat steel fiber. (4) The flexural toughness of wet shotcrete with the silica content of $10 \%$ and the shear steel fiber of $60 \mathrm{~kg} / \mathrm{m}^{3}$ is the best.

\section{Introduction}

With the rapid reduction of traditional resources, the scarcity of resources has become a key factor in restricting economic development. At present, as a raw material widely used in the field of engineering infrastructure, concrete has a huge demand and consumption. So the research on highefficient and environmental-friendly concrete to replace traditional consumption resources is the key to the development of modern concrete. Steel fiber-reinforced siliceous wet shotcrete is a kind of new composite material, which is mixed with steel fiber, silica fume, and high-performance admixtures in common concrete, and the wet method is used in the spray technology. In recent years, shotcrete and castin-situ concrete have been widely used in tunnel support field. Cast-in-situ concrete needs three processes including supporting-formwork, pouring, and demoulding, so the operation is complicated and the cost is high. But shotcrete can be used in high pressure to carry out long-distance transportation, and the supporting efficiency is high. In addition, shotcrete technology can be divided into spray drying and wet spurt. The wet spurt technology has been widely used in the process of tunnel construction, because of its low spring rate and less dust.

The permanent support technique of tunnel single shell lining is mainly divided into three steps. The first step is that waterproof concrete is sprayed in time, after the roadway is excavated. The second step is that cable anchor and steel frame support are carried out according to the surrounding rock classification. The third step is that one or more layers of reference concrete are sprayed. The reference concrete belongs to brittle material, which has many problems such as insufficient mechanical strength index, high hydration heat, and serious self shrinkage. Moreover, the complex force of the shotcrete lining structure in the permanent support of single lining of tunnel, which causes the shotcrete prone to cracking, water inrush, and mud sudden accident [1-3]. Therefore, studying on the mix design method [4] and the mechanical properties of shotcrete $[5,6]$ has become a key in permanent support of tunnel single shell lining. In the past years, schollars had done a lot of research on shotcrete at home and abroad. For example, Zhang et al. [7] had studied the effect of silica fume and fly ash on the performance of shotcrete through laboratory tests. The result of the tests 
concluded that the optimum ratio of new shotcrete can effectively reduce the amount of cement, the cracking, the rebound, and dust. Liu et al. [8] analyzed the shrinkage performance of silica fume concrete through the orthogonal test. The research result indicated that the ratio of water to cement, sand rate, and silica fume addition significantly affected the shrinkage performance of silica fume concrete. Ardalan et al. [9] and Fallah and Nematzadeh [10] found that the strength and durability of shotcrete can be improved by mixing silica fume. Wang et al. [11] and Su et al. [12] found that the mixing of steel fiber can effectively improve the mechanical properties of shotcrete. Naqvi et al. [13] explained the seismic behavior principle of steel fiber shotcrete. Nguyen et al. [14] studied on the impact resistance of steel fiber shotcrete. Nehdi et al. [15] and Hoang and Fehling [16] studied on the effect of steel fiber with different lengths and contents on mechanical properties of shotcrete. Marar et al. [17] discussed the effect of steel fiber with different aspect ratios and contents on shear strength of shotcrete. Yoo et al. [18] analyzed the effect of deformed steel fiber on strength and bending toughness of shotcrete. Nattaj and Nematzadeh [19] obtained the effect of steel fiber with different contents on mechanical properties of silica fume shotcrete. Ghavidel et al. [20] tested on the stability of shotcrete during the steel fiber was pulled out of the shotcrete matrix. Abbass et al. [21] obtained the evaluation method of steel fiber-reinforced concrete with different strength. Zhang et al. [22] had studied the flexural toughness of steel fiber-reinforced wet concrete.

The above scholars had studied the mechanical properties of steel fiber or silica fume shotcrete, but little research had been done on the mechanical properties of steel fiberreinforced siliceous wet shotcrete. Therefore, 10 groups of contrast tests were designed in this paper. The effects of steel fiber-reinforced siliceous on mechanical properties of wet shotcrete were investigated by the test of compressive strength, splitting tensile strength, flexural strength, shear strength, and bending toughness. Finally, the optimum mix ratio of wet shotcrete was obtained. The new steel fiberreinforced siliceous wet shotcrete makes full use of industrial waste to replace nonrenewable raw materials, which has green environmental properties. It also significantly enhances the mechanical strength index, antiseepage, and anticracking ability. Moreover, it not only improves the supporting effect of tunnel engineering, but also avoids the occurrence of water bursting and mud outburst.

\section{Experimental}

2.1. Raw Material. The shotcrete of this test adopted No. 42.5 Portland cement. The fine aggregate was sand, and the fineness modulus was 2.64. The well-graded coarse aggregate was crushed stone, and the particle size was 5$10 \mathrm{~mm}$. Silica fume was produced by Ark New Materials (Shandong) Co., Ltd. The performance parameters of silica fume are shown in Table 1 . Steel fiber was produced by Huaxing(Yueyang)Co., Ltd. It was divided into two types: shear undaform and shear flat. Its specific parameters are shown in Table 2. The admixture adopted a low alkaline liquid setting accelerator of FZ-100C. Photographs of steel fiber and silica fume are shown in Figure 1.

2.2. Mix Proportion Design of Wet Shotcrete. The specification GB 50086-2015 of bolt shotcrete support technology was used to carry out the mix proportion design of wet shotcrete. The dust, resilience, and pumping capacity of wet shotcrete were also considered. The apparent density of shotcrete was $2400 \mathrm{~kg} / \mathrm{m}^{3}$. The ratio of cement to sand was $1: 2.4$. The water-cement ratio was 0.55 . The content of gravel was $598 \mathrm{~kg} / \mathrm{m}^{3}$. The silica fume was $10 \%$ cement quality. The content of accelerator was $1.2 \mathrm{~kg} / \mathrm{m}^{3}$, and accelerator was $5 \%$ cement quality. The maximum content of steel fiber was $60 \mathrm{~kg} / \mathrm{m}^{3}$. There were 10 groups of contrast tests, and the specific mix proportion of each group is shown in Table 3.

2.3. Experimental Method. The experiment was divided into ten groups, with 15 specimens in each group. The 6 cube specimens of $100 \mathrm{~mm} \times 100 \mathrm{~mm} \times 100 \mathrm{~mm}$ were used to carry out the tests of compressive and splitting tensile strength. The 3 cube specimens of $100 \mathrm{~mm} \times 100 \mathrm{~mm}$ $\times 300 \mathrm{~mm}$ were used to carry out the test of shear strength. The 6 rectangular specimens of $100 \mathrm{~mm} \times 100 \mathrm{~mm} \times 400 \mathrm{~mm}$ were used to carry out the tests of flexural and bending toughness strength. This test adapted forced action mixer of $60 \mathrm{~L}$. The time of entry template was 4 minutes later, and the time of dismantling template was $24 \mathrm{~h}$ later. The vibrating time was $60 \mathrm{~s}$. The specimens shall be carried out for 28 days at standard curing condition. The electronic universal testing machine CSS44100 of $300 \mathrm{kN}$ was used by this test, and the method of steel fiber concrete JG/T 472-2015 was used to carry out the continuous loading on shotcrete specimens. The test of bending toughness adopted the loading method of four-point bending, and the loading rate was $0.2 \mathrm{~mm} / \mathrm{min}$. When the discreteness was lower, the wet shotcrete intensity of this group was defined as the average value of the intensities of three specimens. When it was higher, the wet shotcrete intensity of a group was defined as the median value of the intensities of three specimens if the difference between the maximum or minimum value and the median value was larger than 15 percent of the median value, if not, this experiment was invalid. The electronic universal testing machine is shown in Figure 2.

\section{Results and Discussion}

3.1. Combined Effect of Silica Fume and Steel Fiber. Table 4 shows the test results of compression, splitting tensile, flexural, shear, and first-crack strength.

Comparison of group 2 and group 1 shows that when silica fume was mixed only, the compressive strength, splitting tensile strength, flexural strength, shear strength, and initial splitting strengths of silica fume concrete were improved by $15.94 \%, 7.53 \%, 37.97 \%, 50.56 \%$, and $18.92 \%$, respectively, compared with the reference concrete. This showed that silica fume had a good enhancement effect. The silica fume of high pozzolanic activity and water did not 
TABLE 1: Silica fume performance parameter.

\begin{tabular}{lcccc}
\hline Average particle size $(\mu \mathrm{m})$ & Specific surface area $\left(\mathrm{m}^{2} \cdot \mathrm{kg}^{-1}\right)$ & Fineness $(\%)$ & Density $\left(\mathrm{g} / \mathrm{cm}^{3}\right)$ \\
\hline 0.1 & 15000 & 0.05 & 2.3 \\
\hline
\end{tabular}

TABLE 2: Steel fiber performance parameter.

\begin{tabular}{lcccc}
\hline Steel fiber type & Length $(\mathrm{mm})$ & Equivalent diameter $(\mathrm{mm})$ & Aspect ratio & Tensile strength \\
\hline Shear undaform & 30 & 0.3 & 100 & Greater than $1150 \mathrm{MPa}$ \\
Shear flat & 25 & 0.3 & 83 & Greater than $1150 \mathrm{MPa}$ \\
\hline
\end{tabular}

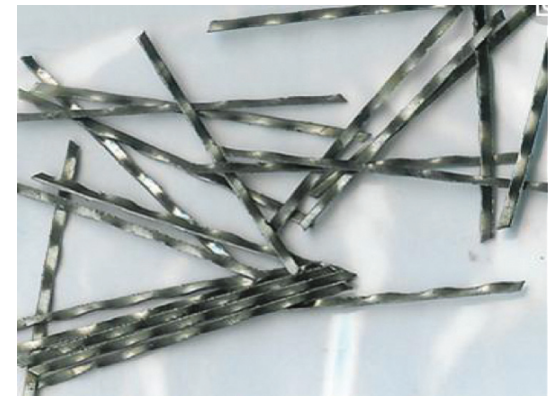

(a)

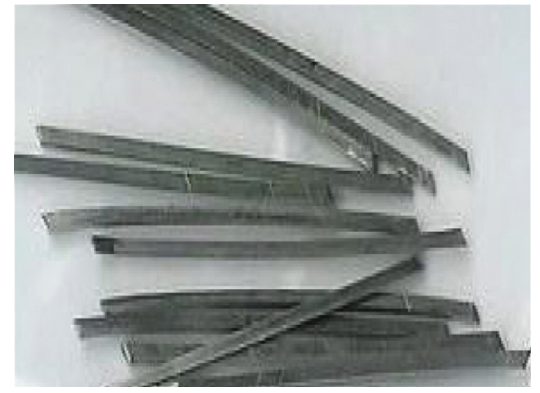

(b)

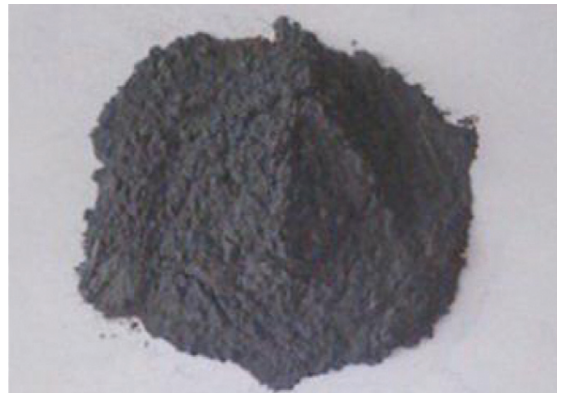

(c)

Figure 1: (a) Shear undaform steel fiber. (b) Shear flat steel fiber. (c) Silica fume.

TABle 3: Mix proportion of wet shotcrete.

\begin{tabular}{lcccccc}
\hline Group & Water-cement ratio & Accelerator $\left(\mathrm{kg} / \mathrm{m}^{3}\right)$ & Gravel $\left(\mathrm{kg} / \mathrm{m}^{3}\right)$ & Silica fume & Steel fiber shape & Steel fiber content $\left(\mathrm{kg} / \mathrm{m}^{3}\right)$ \\
\hline 1 & 0.55 & 1.2 & 598 & Nothing & Nothing & 0 \\
2 & 0.55 & 1.2 & 598 & $10 \%$ cement quality & Nothing & 0 \\
3 & 0.55 & 1.2 & 598 & Nothing & Shear undaform & 50 \\
4 & 0.55 & 1.2 & 598 & Nothing & Shear flat & 50 \\
5 & 0.55 & 1.2 & 598 & $10 \%$ cement quality & Shear undaform & 50 \\
6 & 0.55 & 1.2 & 598 & $10 \%$ cement quality & Shear flat & 50 \\
7 & 0.55 & 1.2 & 598 & $10 \%$ cement quality & Shear undaform & 60 \\
8 & 0.55 & 1.2 & 598 & $10 \%$ cement quality & Shear flat & 60 \\
9 & 0.55 & 1.2 & 598 & $10 \%$ cement quality Shear undaform & 40 \\
10 & 0.55 & 1.2 & 598 & $10 \%$ cement quality & Shear flat & 40 \\
\hline
\end{tabular}

involve in the hydration reaction but silica fume and hydration product $\mathrm{Ca}(\mathrm{OH})_{2}$ of cement involved in the secondary hydration reaction to produce $\mathrm{C}-\mathrm{S}-\mathrm{H}$ gel, thus improving viscosity of the mixture. In addition, the microscopic pore structure of hardened cement paste can be filled with silica fume with microaggregate effect and secondary hydration products. Not only it can improve the microscopic pore structure but also increase the density and strength of silica fume concrete.

Comparison of group 3 and group 1 shows that when shear undaform steel fiber was mixed only, the compressive strength, splitting tensile strength, flexural strength, shear strength, and initial splitting strength of steel fiber concrete were improved by $18.12 \%, 33.33 \%, 39.57 \%, 78.09 \%$, and $28.38 \%$, respectively, compared with the reference concrete. It concluded that the crack resistance of steel fiber was better than that of silica fume. Moreover, the splitting tensile strength, flexural strength, and shear strength of the steel fiber concrete were obviously improved. Due to gravity, steel fibers and solid particulate matter took place subsidence during the hardening process of steel fiber-reinforced concrete, but the distributed steel fiber hindered the subsidence of the solid particles, and it played a reinforcing role, which increased the density of the steel fiber concrete and reduced the occurrence of the original microcracks. In addition, the bridging action of the steel fiber across the cracks prevented the coalescence of microcracks, and it reduced the depth and number of cracks, thus played a role in crack resistance.

Comparison of group 5 and group 1 shows that when shear undaform steel fiber of $50 \mathrm{~kg} / \mathrm{m}^{3}$ and silica fume were mixed together, the compressive strength, splitting tensile 


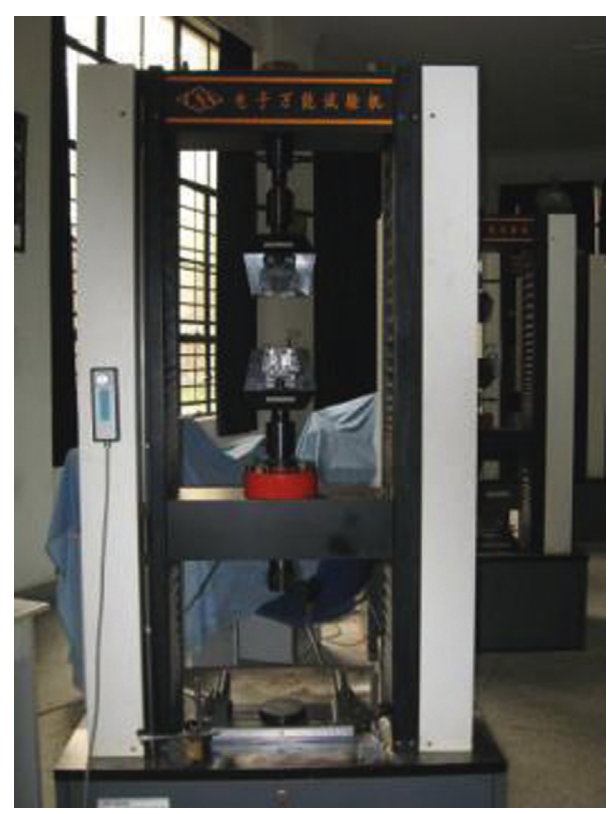

Figure 2: Electronic universal testing machine.

TABLE 4: Test results of compression, splitting tensile, flexural, shear, and first-crack strength.

\begin{tabular}{lccccc}
\hline Group & $\begin{array}{c}\text { Compressive strength } \\
(\mathrm{MPa})\end{array}$ & $\begin{array}{c}\text { Splitting tensile strength } \\
(\mathrm{MPa})\end{array}$ & $\begin{array}{c}\text { Bending strength } \\
(\mathrm{MPa})\end{array}$ & $\begin{array}{c}\text { Shear strength } \\
(\mathrm{MPa})\end{array}$ & $\begin{array}{c}\text { First-crack strength } \\
(\mathrm{MPa})\end{array}$ \\
\hline 1 & 13.8 & 0.93 & 1.87 & 1.78 & 1.48 \\
2 & 16 & 1 & 2.58 & 2.68 & 1.76 \\
3 & 16.3 & 1.24 & 2.61 & 3.17 & 1.9 \\
4 & 1.9 & 1.1 & 3 & 3.3 & \\
5 & 17.1 & 1.62 & 2.89 & 3.13 & 1.88 \\
6 & 17 & 1.48 & 3.23 & 3.53 & 1.97 \\
7 & 17.8 & 1.65 & 3.11 & 3.44 & 2.03 \\
8 & 17.4 & 1.61 & 2.7 & 2.83 & 1.98 \\
9 & 16.8 & 1.52 & 2.59 & 2.73 & 1.95 \\
10 & 16.6 & 1.31 & & \\
\hline
\end{tabular}

strength, flexural strength, shear strength, and initial splitting strength of steel fiber-reinforced siliceous shotcrete were improved by $23.91 \%, 74.19 \%, 60.43 \%, 85.39 \%$, and $33.11 \%$, respectively, compared with the reference concrete. It found that the edge of the reference concrete was broken and dropped seriously, and there was an explosive spalling phenomenon during the test. Finally, brittle failure took place. The steel fiber-reinforced siliceous shotcrete was relatively complete during the test, and there was no shedding dregs phenomenon. Finally, ductile failure took place. The C-S-H gel produced by secondary hydration can increase the cohesion force between the matrix and the steel fiber. So, it not only decreased segregation and bleeding of aggregate but also reduced the shrinkage of hardening cement paste.

By comparing the data, it is concluded that the compressive strength of steel fiber-reinforced siliceous shotcrete was not very different from the former two kinds of concrete. When shotcrete was subjected to axial pressure, the lateral expansion deformation of the shotcrete was restrained. Because of the cohesive force between the steel fiber and the matrix, the compressive strength can only be indirectly improved. Therefore, the effect of compression was not obvious.

But the splitting tensile strength, flexural strength, shear resistance, and initial crack strength of steel fiber-reinforced siliceous shotcrete had obvious effect on enhancement and crack resistance. However, the steel fiber and the matrix beared the load together, which hindered the extension and expansion of crack in the initial loading process. When the ultimate limit load of the matrix was reached, the steel fibers of across or near the crack tip played a bridging action, which forced the crack to change the direction of development or destroy the steel fiber. When the ultimate limit load was reached, pulling-out and shearing phenomena took place during the test. The pulling out, debonding, and destruction of steel fibers with high modulus of elasticity consumed most of the fracture energy, so it can greatly increase the splitting tensile strength, flexural strength, and shear strength of steel fiber-reinforced siliceous shotcrete.

Finally, the macrocracks of steel fiber-reinforced siliceous shotcrete were expanding and coalescence. Ductile 
failure took place because of the short bearing capacity of steel fiber and matrix together. A comparison of compressive and shear failure of steel fiber-reinforced siliceous shotcrete is shown in Figures 3 and 4.

\subsection{Influence of Steel Fiber Content and Type.} Comparison of groups 1 and 5-10 in Table 4 shows that when the content of shear undaform steel fiber was increased from $40 \mathrm{~kg} / \mathrm{m}^{3}$ to $50 \mathrm{~kg} / \mathrm{m}^{3}$ and $60 \mathrm{~kg} / \mathrm{m}^{3}$, the growth rate of compressive strength and initial crack strength of steel fiberreinforced siliceous shotcrete was little changed. For compressive strength, the content of steel fiber can not change the lateral expansion limited deformation and then indirectly increased the compressive strength. For the initial crack strength, the steel fiber and the matrix beared the load together before the initial crack. The matrix was unloaded but the load was carried by the steel fiber after the initial crack. Finally, it reached the limit load. The initial crack strength of steel fiber-reinforced siliceous shotcrete was mainly controlled by the matrix, while the limited strength was mainly controlled by steel fiber. Therefore, the content of steel fiber had little influence on the initial crack strength of steel fiber-reinforced siliceous shotcrete.

When the content of steel fiber was increased from $40 \mathrm{~kg} / \mathrm{m}^{3}$ to $50 \mathrm{~kg} / \mathrm{m}^{3}$, the growth rate of splitting tensile strength, flexural strength, and shear strength of steel fiberreinforced siliceous shotcrete was very greatly changed; but from $50 \mathrm{~kg} / \mathrm{m}^{3}$ to $60 \mathrm{~kg} / \mathrm{m}^{3}$, the growth rate was gradually decreased. With the increasing content of steel fiber and nonmixing uniformity of shotcrete, which reduced the slump and workability of shotcrete. So it gradually increased porosity and microcracks. Some steel fibers appeared to the agglomerates by observing the cross section of steel fiberreinforced siliceous shotcrete.

Comparison of group 5 and group 6, group 7 and group 8 , and group 9 and group 10 shows that the shape of the steel fiber had little effect on the compressive strength, but the splitting tensile strength, flexural strength, shear strength, and initial crack strength of mixing the shear undaform steel fiber were about $10 \%$ higher than that of mixing the shear flat steel fiber. Because the special section of shear undaform steel fiber had anchoring effect, and the bonding area was large between shear undaform steel fiber and matrix, which increased the cohesion force. So pulling out, tensile failure, and shearing of undaform steel fiber required higher energy. The steel fiber-reinforced siliceous shotcrete section is shown in Figure 5.

\subsection{Analysis and Evaluation of Bending Toughness of Wet} Shotcrete. According to the JG/T 472-2015 test method of steel fiber concrete, the bending toughness index and the variation coefficients of load-carrying capability were calculated. The bending toughness of wet shotcrete was evaluated by comparing two parameters with two parameters of the ideal elastoplastic material. The bending toughness index was expressed by $I_{5}, I_{10}$, and $I_{30}$, and the variation coefficients of load-carrying capability was expressed by $\xi_{m, n, 5}$, $\xi_{m, n, 10}$, and $\xi_{m, n, 30}$. The bending toughness test results are shown in Table 5, and the load deflection curves of different types of wet shotcrete are shown in Figure 6.

As is shown in Table 5, when silica fume was mixed only, wet shotcrete took place brittle failure rapidly after reaching the initial crack strength. So silica fume can not improve the bending toughness of wet shotcrete. When shear undaform steel fiber of $50 \mathrm{~kg} / \mathrm{m}^{3}$ was mixed only, the $I_{5}, I_{10}$, and $I_{30}$ of wet shotcrete was $4.86,9.26$, and 24.91 , which was significantly higher than that of reference concrete. When shear undaform steel fiber of $50 \mathrm{~kg} / \mathrm{m}^{3}$ and silica fume were added together, the $I_{5}, I_{10}$, and $I_{30}$ of wet shotcrete were increased by $0.35,0.47$, and 1.96 , respectively, compared with steel fiber concrete. Although the bending toughness index had been improved to some extent, it had not changed greatly. When the content of shear undaform steel fiber was increased from $40 \mathrm{~kg} / \mathrm{m}^{3}$ to $50 \mathrm{~kg} / \mathrm{m}^{3}$, the bending toughness index had changed greatly. But from $50 \mathrm{~kg} / \mathrm{m}^{3}$ to $60 \mathrm{~kg} / \mathrm{m}^{3}$, its growth rate was decreased obviously.

As is shown in Figure 6, the peak load of the seventh group of shotcrete was maximum. At first, the bending deformation ability was not as good as that of the ninth group, and the ninth group was declined faster. But the bending deformation ability of the seventh group was more than the ninth group beyond a certain deflection. When the content of steel fiber exceeded a certain limit, the improvement effect of bending toughness was weakened. The bending toughness index of mixing the shear undaform steel fiber was slightly larger than that of mixing the shear flat steel fiber. The change trend of the variation coefficients of load-carrying capability was similar to the bending toughness index, and the change mechanism of bending toughness was similar to splitting tensile strength. The content of silicon fume was cement quality of $10 \%$ and shear undaform steel fiber was $60 \mathrm{~kg} / \mathrm{m}^{3}$, and the bending toughness of wet shotcrete was the best by comprehensive analysis.

\section{Conclusions}

(1) The mixing of steel fiber and silica fume can significantly improve the splitting tensile strength, flexural strength, shear strength, and bending toughness of wet shotcrete. The steel fiber played a major role, and silica fume played a subsidiarity role. When the content of shear undaform steel fiber was $60 \mathrm{~kg} / \mathrm{m}^{3}$, the maximum growth rate of the shear strength was $98.31 \%$.

(2) The effect of different types and contents of steel fibers on the compressive strength of wet shotcrete was not obvious. When shear undaform steel fiber and silica fume were mixed together, the maximum growth rate of the compressive strength was $28.99 \%$.

(3) When steel fiber and silica fume were mixed together, the splitting tensile strength, flexural strength, shear strength, and initial crack strength of mixing the shear undaform steel fiber were about $10 \%$ higher than that of mixing the shear flat steel fiber. 


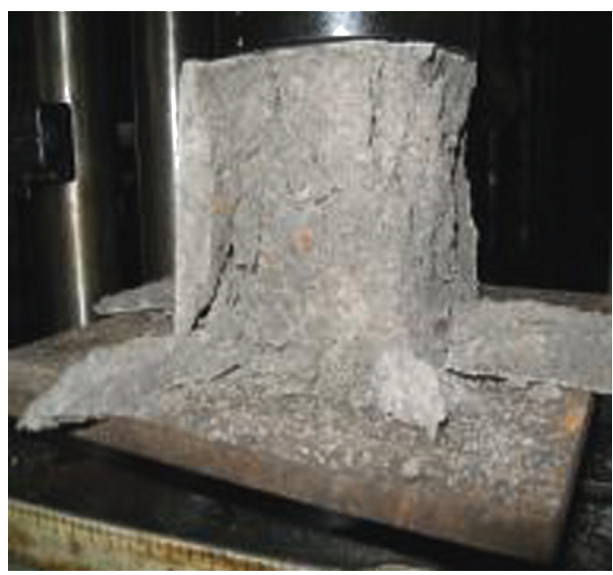

(a)

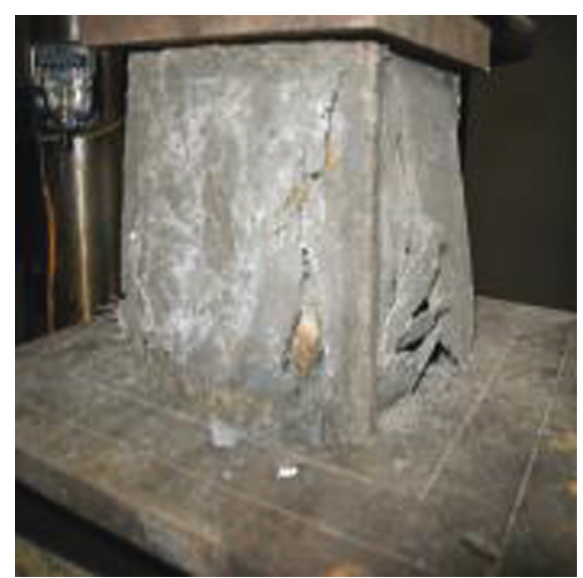

(b)

FIgURE 3: Compression failure true thickness. (a) Reference concrete. (b) Steel fiber-silica fume shotcrete.

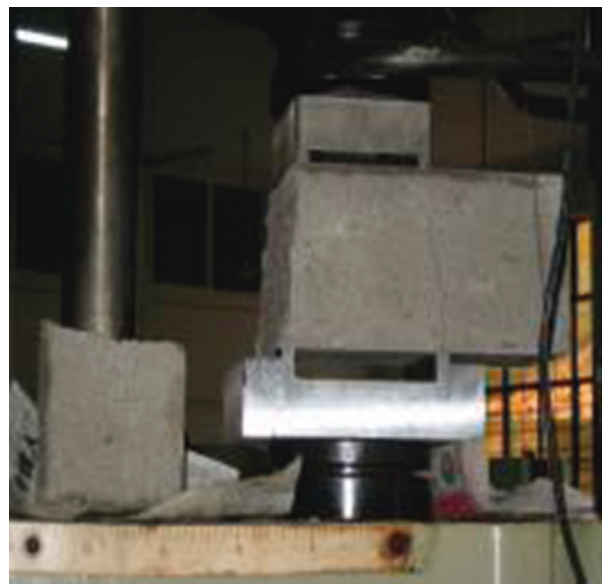

(a)

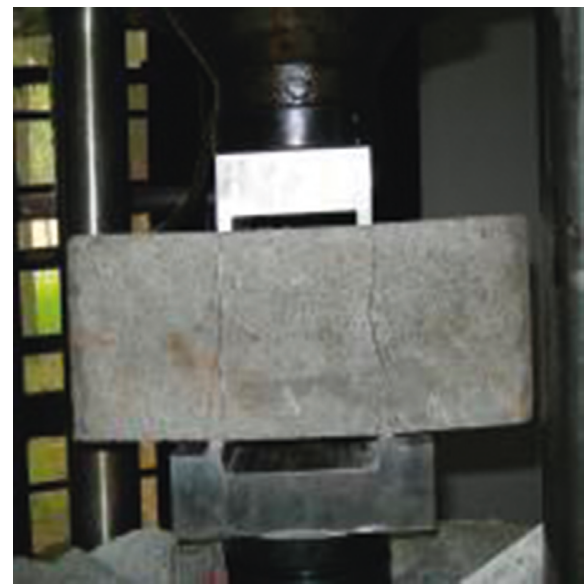

(b)

Figure 4: Shear failure true thickness. (a) Reference concrete. (b) Steel fiber-silica fume shotcrete.

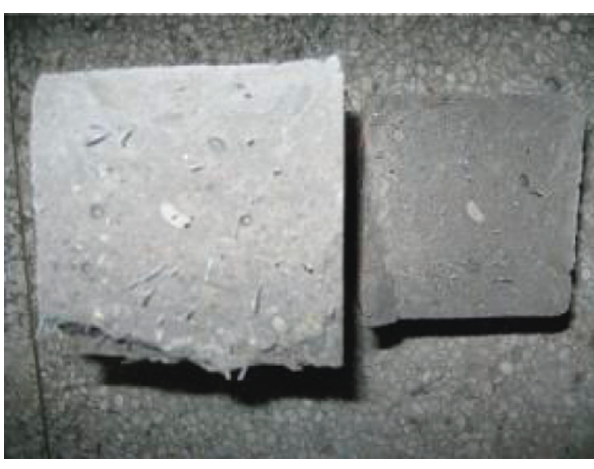

(a)

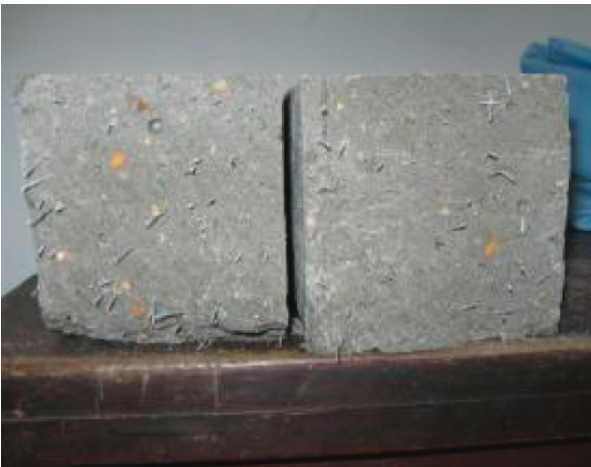

(b)

FIgURE 5: Section of steel fiber-reinforced silica fume concrete.

(4) When silica fume was mixed only, it can not improve the bending toughness of wet shotcrete. When steel fiber and silica fume were mixed together, the bending toughness index had a little improved. The seventh group of wet shotcrete was the optimum mixture ratio; moreover, the bending toughness 
TABLE 5: Test results of bending toughness.

\begin{tabular}{lcccccccc}
\hline Group & Cracking load $(N)$ & Cracking deflection $(0.01 \mathrm{~mm})$ & $I_{5}$ & $I_{10}$ & $I_{30}$ & $\xi_{m, n, 5}$ & $\xi_{m, n, 10}$ & $\xi_{m, n, 30}$ \\
\hline 1 & 4944 & 8.7 & 1 & 1 & 1 & 0 & 0 \\
2 & 5868 & 9.5 & 1 & 1 & 1 & 0 & 0 \\
3 & 6349 & 10.3 & 4.86 & 9.26 & 24.91 & 0.93 & 0.84 & 0.65 \\
4 & 6258 & 9.9 & 4.63 & 9.07 & 24.38 & 0.82 & 0.79 & 0.61 \\
5 & 6506 & 10.4 & 5.21 & 9.73 & 26.87 & 1.11 & 0.94 & 0.78 \\
6 & 6489 & 9.9 & 4.92 & 9.49 & 26.09 & 0.96 & 0.89 & 0.73 \\
7 & 6756 & 10.7 & 5.34 & 9.92 & 27.53 & 1.17 & 0.98 & 0.83 \\
8 & 6606 & 10.5 & 5.13 & 9.67 & 26.89 & 1.07 & 0.93 & 0.79 \\
9 & 6497 & 10.2 & 4.98 & 9.45 & 25.65 & 0.99 & 0.88 & 0.7 \\
10 & 6443 & 9.7 & 4.75 & 9.31 & 25.28 & 0.88 & 0.85 & 0.67 \\
\hline
\end{tabular}

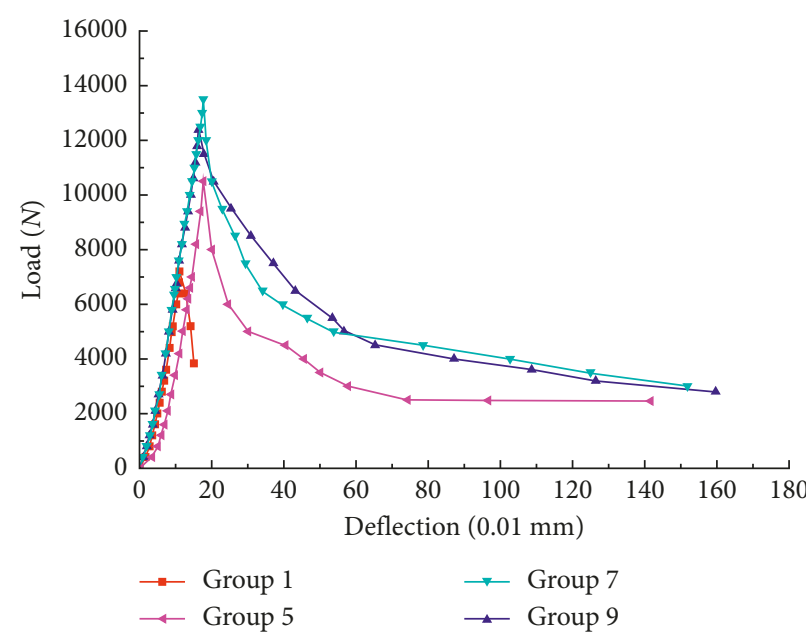

(a)

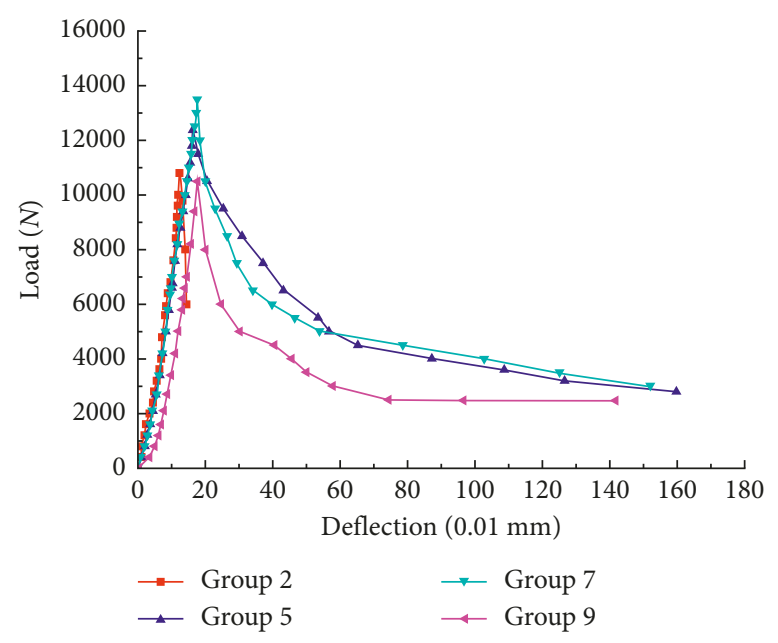

(b)

Figure 6: Shotcrete load-deflection curve. (a) Comparison of shear undaform steel fiber concrete and reference concrete. (b) Comparison of shear undaform steel fiber concrete and silica fume concrete.

index and the variation coefficients of load-carrying capability were closest to the corresponding parameters of ideal elastic-plastic material.

(5) The ordinary steel fiber-reinforced wet shotcrete has been initially applied in the tunnel of Brunel Thames in Britain and the Riva tunnel in Turkey, but the steel fiber-reinforced siliceous wet shotcrete could more effectively enhance the antiseepage and anticracking ability of tunnels, underground stations, and mine construction. Moreover, it could also avoid the water inrush and mud outburst disaster.

\section{Data Availability}

The data used to support the findings of this study are available from the corresponding author upon request.

\section{Conflicts of Interest}

The authors declare that they have no conflicts of interest.

\section{Acknowledgments}

This work was fully supported by the Key Research and Development Plan of Shandong Province of China (2018GSF116006).

\section{References}

[1] M. Rostami and K. Behfarnia, "The effect of silica fume on durability of alkali activated slag concrete," Construction and Building Materials, vol. 134, pp. 262-268, 2017.

[2] A. J. Daniel, S. Sivakamasundari, and A. Nishanth, "Study on partial replacement of silica fume based geopolymer concrete beam behavior under torsion," Procedia Engineering, vol. 173, pp. 732-739, 2017.

[3] K. Alireza, M. R. Elias, H. Payam, and T. Hamidreza, "Mechanical performance of self-compacting concrete reinforced with steel fibers," Construction and Building Materials, vol. 51, pp. 179-186, 2014.

[4] J. Yu, S. M. Lei, X. W. Liang et al., "A design method of mix proportion for a new type of hybrid steel fiber reinforced self 
compacting concrete," Journal of Building Materials, vol. 20, no. 4, pp. 611-615, 2017.

[5] W. F. Cheng, X. P. Lin, Y. N. Ding et al., "Study on engineering application of silica fume additives and steel fiber shotcrete," Journal of Rock Mechanics and Engineering, vol. 30, no. 11, pp. 2311-2329, 2011.

[6] X. R. Liu, Y. H. Zhu, X. H. Li et al., "Experimental research on single-layer tunnel lining of steel fiber shotcrete," Geotechnical Mechanics, vol. 30, no. 8, pp. 2319-2323, 2009, in Chinese.

[7] L. C. Zhang, S. C. Li, S. Li et al., "Influence of silica fume and fly ash on Shotcrete performance," Journal of Shandong University, vol. 46, no. 5, pp. 103-109, 2016, in Chinese.

[8] Y. Liu, R. Ma, J. Yang et al., "Shrinkage properties of silica fume concrete," Journal of Guangxi University, vol. 40, no. 4, pp. 909-914, 2015, in Chinese.

[9] R. B. Ardalan, A. Joshaghani, and R. D. Hooton, "Workability retention and compressive strength of self-compacting concrete incorporating pumice powder and silica fume," Construction and Building Materials, vol. 134, pp. 116-122, 2017.

[10] S. Fallah and M. Nematzadeh, "Mechanical properties and durability of high-strength concrete containing macropolymeric and polypropylene fibers with nano-silica and silica fume," Construction and Building Materials, vol. 132, pp. 170-187, 2017.

[11] L. C. Wang, P. Q. Jiang, Y. Q. Liang et al., "Experimental study on dynamic mechanical properties of steel fiber concrete under biaxial compression," Journal of Building Materials, vol. 20, no. 1, pp. 106-111, 2017.

[12] C. D. Su, Y. Li, Z. Q. Xiong et al., "Splitting strength and deformation characteristics of steel fiber reinforced high performance concrete," Journal of Building Materials, vol. 17, no. 4, pp. 587-591, 2014.

[13] S. Naqvi, K. Mahmoud, and E. El-Salakawy, "Effect of axial load and steel fibers on the seismic behavior of lap-spliced glass fiber reinforced polymer-reinforced concrete rectangular columns," Engineering Structures, vol. 134, pp. 376-389, 2017.

[14] T. Nguyen, T. T. Nguyen, and W. Pansuk, "Experimental study of the punching shear behavior of high performance steel fiber reinforced concrete slabs considering casting directions," Engineering Structures, vol. 131, pp. 564-573, 2017.

[15] M. L. Nehdi, S. Abbas, and A. M. Soliman, "Exploratory study of ultra-high performance fiber reinforced concrete tunnel lining segments with varying steel fiber lengths and dosages," Engineering Structures, vol. 101, pp. 733-742, 2015.

[16] A. L. Hoang and E. Fehling, "Influence of steel fiber content and aspect ratio on the uniaxial tensile and compressive behavior of ultra high performance concrete," Construction and Building Materials, vol. 153, pp. 790-2806, 2017.

[17] K. Marar, Ö. Eren, and H. Roughani, "The influence of amount and aspect ratio of fibers on shear behaviourof steel fiber reinforced concrete," Journal of Civil Engineering, vol. 21, no. 4, pp. 1393-1399, 2017.

[18] D. Y. Yoo, S. W. Kim, and J. J. Park, "Comparative flexural behavior of ultra-high-performance concrete reinforced with hybrid straight steel fibers," Construction and Building Materials, vol. 132, pp. 219-2229, 2017.

[19] F. H. Nattaj and M. Nematzadeh, "The effect of forta-ferro and steel fibers on mechanical properties of high-strength concrete with and without silica fume and nano-silica," Construction and Building Materials, vol. 137, pp. 557-572, 2017.

[20] R. Ghavidel, R. Madandoust, and M. M. Ranjbar, "Reliability of pull-off test for steel fiber reinforcedself -compacting concrete," Measurement, vol. 73, pp. 628-639, 2015.
[21] W. Abbass, M. I. Khan, and S. Mourad, "Evaluation of mechanical properties of steel fiber reinforced concrete with different strengths of concrete," Construction and Building Materials, vol. 168, pp. 556-569, 2018.

[22] J. P. Zhang, L. M. Liu, Z. D. Zhu, and J. Z. Cao, "Flexural fracture toughness and first-crack strength tests of steel fibersilica fume concrete and its engineering applications," Strength of Materials, vol. 50, no. 1, pp. 166-175, 2018. 


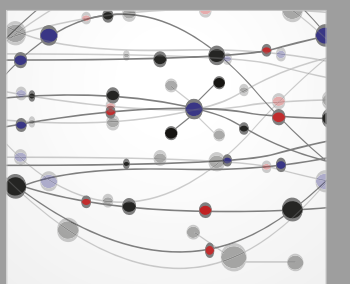

The Scientific World Journal
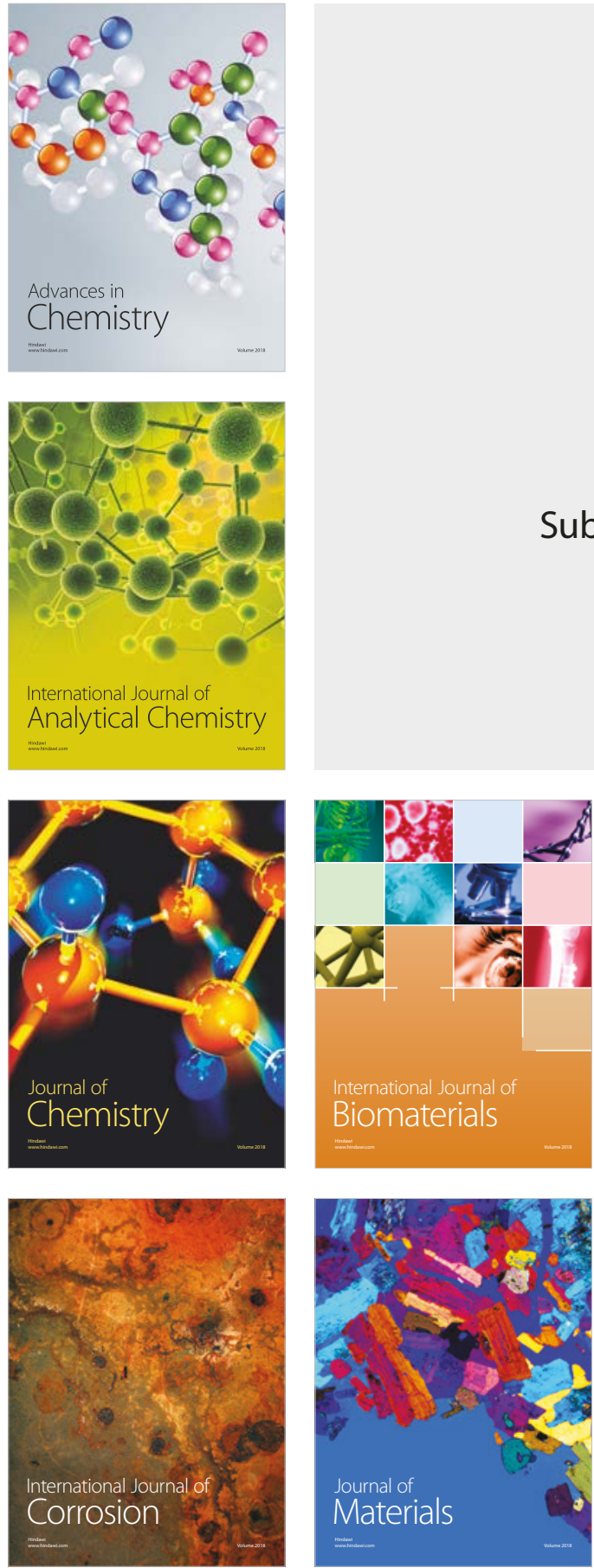

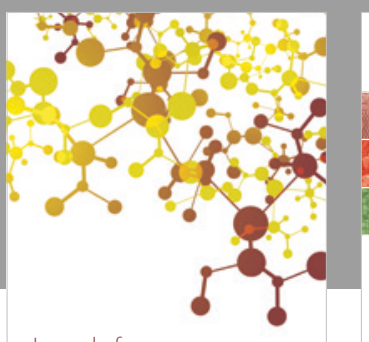

Journal of

Applied Chemistry
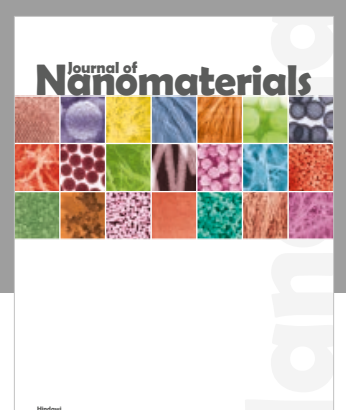

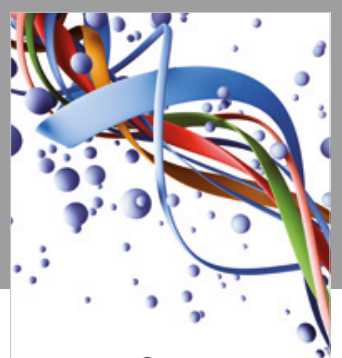

Scientifica

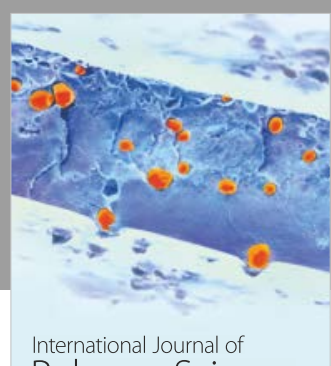

Polymer Science

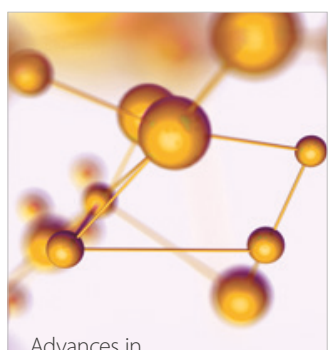

Physical Chemistry
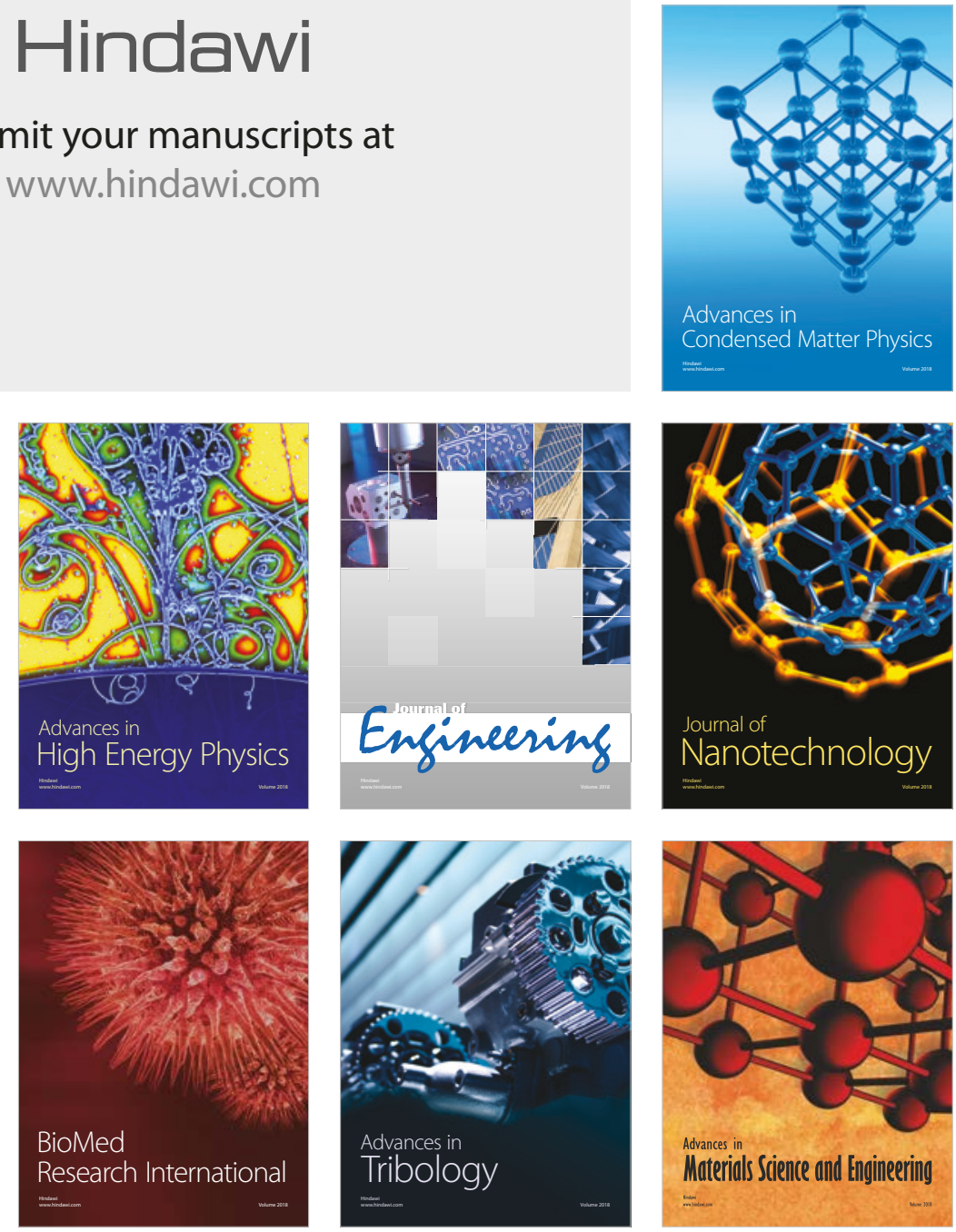